\title{
Health education during antenatal care: the need for more
}

\author{
This article was published in the following Dove Press journal: \\ International Journal of Women's Health \\ 18 February 2015 \\ Number of times this article has been viewed
}

\author{
Mohammed A Al-Ateeq' \\ Amal A Al-Rusaiess ${ }^{2}$ \\ 'College of Medicine, King Saud Bin \\ Abdul-Aziz University for Health \\ Sciences, ${ }^{2}$ Department of Family \\ Medicine and Primary Health Care, \\ King Abdul-Aziz Medical City, \\ National Guard Health Affairs, Riyadh, \\ Kingdom of Saudi Arabia
}

\begin{abstract}
The aim of health education during antenatal is to provide advice, education, reassurance and support, to address and treat the minor problems of pregnancy, and to provide effective screening during the pregnancy. Exploring current practices in this regard revealed the need for more organized educational activities to ensure high quality and clients satisfaction. Keywords: antenatal care, health education, pregnant women, postpartum, misconceptions
\end{abstract}

\section{Introduction}

Antenatal care (ANC) is a careful, systematic assessment and follow-up of pregnant women, that includes education, counseling, screening, and treatment to assure the best possible health of the mother and her fetus. ${ }^{1}$

The ANC program was designed in Europe in the first decades of the 20th century and was first directed at women in socially difficult living conditions, with the objective of improving maternal and prenatal outcomes. ${ }^{2,3}$ Gradually, ANC was expanded to include more specific screening procedures to detect defined medical problems for all pregnant women. As maternal and prenatal outcomes dramatically improved in the industrialized parts of the world, ANC was given much of the credit without evidence of its exact benefit. ${ }^{2,4,5}$

The principles of ANC for women with uncomplicated pregnancies are to provide advice, education, reassurance, and support; to address and treat the minor problems of pregnancy; and to provide effective screening during the pregnancy. ${ }^{6}$

The concept of quality of care is increasingly recognized as a key element in the provision of health care, and it is associated with the outcomes of care in terms of effectiveness, compliance, and continuity of care. In light of this, recent recommendations for ANC stress the need to address both the psychosocial and medical needs of women, ${ }^{7}$ as well as the concept of the new ANC model, as promoted by the World Health Organization (WHO), reflects the new understanding of the role of ANC. ${ }^{8}$

World Health Report 2005 calls for "realizing the Potential of Antenatal Care." While ANC interventions, in and of themselves, cannot be expected to have a major impact on maternal mortality, their purpose is to improve maternal and perinatal health. ${ }^{10}$ In addition, the potential of ANC as a line of action to increase the rate of births attended by skilled health staff, and its value as entry point for other health programs such as nutrition, is now better understood and applied. ${ }^{9-12}$

Each of the ANC visits consists of a well-defined set of activities related to three equally important general areas, namely screening for conditions likely to increase adverse outcomes, providing therapeutic interventions known to be beneficial, and educating pregnant women about planning for a safe birth, emergencies during pregnancy, and how to deal with them. ${ }^{8}$ 
There were many studies done which found that educated women have better pregnancy outcomes compared with uneducated women and that education during the antenatal period can reduce pregnancy and delivery complications. ${ }^{13-16}$

Education is an important component of prenatal care, particularly for women who are pregnant for the first time. ${ }^{17,18}$ The three studies done in Gambia, supported that provision of information and education is a major component of ANC. ${ }^{19-21}$

ANC provides an important opportunity for discussion between a pregnant women and a health care provider about health behavior during pregnancy and about recognizing complications that may arise during pregnancy. ANC personnel should also provide information on postpartum care, newborn care, breastfeeding, signs of problems, and appropriate action to take. ${ }^{11}$

In a study done in four developing countries (Argentina, Cuba, Thailand, and Saudi Arabia), it was found that women want more information on the psychosocial aspects of pregnancy. ${ }^{22}$ The information received from providers is an important issue for Saudi women. Another study among the same countries revealed that women were satisfied with the information received about normal labor, breastfeeding, family planning, danger signs, and on how to recognize problems and what to do to manage them. ${ }^{23}$ In another study, the majority felt that some topics should be addressed more in depth, such as nutrition and the type of food they can and cannot eat. ${ }^{24}$ One of the main goals of the new model of care was to strengthen the information component. ${ }^{25}$

Satisfaction of the people seeking help, is one of the most important qualitative indexes of health care provision, and has a very special importance in prenatal care. Satisfying pregnant women is achieved through satisfying their needs and expectations. ${ }^{26}$

There were several studies done to address women's satisfaction with prenatal care received at the primary health care centers. ${ }^{24,27}$ Sixty percent of the mothers had very low or low satisfaction with the information they received during prenatal care, while (39.8\%) of them were very highly or highly satisfied, with significant correlation between this satisfaction and some variables. ${ }^{27}$

Study of maternal deaths suggested that low levels of awareness of danger signs of pregnancy and delivery contribute to high maternal mortality ratios in a country. ${ }^{28}$

Another study, found that health education and counseling has been identified as the major gap between the current performance and the proper performance of focused ANC. ${ }^{29}$

A single antenatal visit does not give information about the completeness and components of the care provided.
Additional indicators were the number of visits (it is recommended by WHO that at least four are made during the pregnancy) and the timing (ideally, ANC should be initiated within the first 12 weeks of pregnancy).

Use of ANC early in the pregnancy is professionally considered important to ensure that appropriate ANC is arranged and, therefore, good quality and quantity of information with education are delivered to improve pregnancy outcomes. A study found that women were not compliant with the recommended time of the first visit of pregnancy. Instead, most women make their first visit after 21 weeks or when the pregnancy started showing. The listed reasons included shame for having too many pregnancies or being over 40 years old and pregnant. Women also mentioned servicerelated reasons; for example, negative attitudes of service providers and poor quality of care. ${ }^{30}$ There were studies done which revealed that multiparous women and older women preferred fewer visits as a result of the experience they had during previous pregnancies. ${ }^{30,31}$

In regard to the source of education during $\mathrm{ANC}$, in a study conducted in four developing countries, including Saudi Arabia, women said that they get the information from doctors in the consultations. They also said that quite frequently, information is provided by nurses and not by doctors. ${ }^{22}$

It is a well known fact that literacy among women in many developing countries is low, and there are sociocultural beliefs and practices with adverse effects on pregnancy and birth occurring even among educated women. ${ }^{32}$ In all societies, health beliefs are among those held most tenaciously and are an integral aspect of a culture. ${ }^{33}$ Individual health behaviors are embedded in cultural pattern exchanges and are usually transmitted from generation to generation. ${ }^{34}$

A qualitative study of ANC in a rural area of Zimbabwe showed that cultural beliefs had great influence, especially at the time a pregnancy is acknowledged and reported. And it was found that ANC ignores the experiences and views of women regarding the care of pregnancy. ${ }^{30}$

A study done in a rural area of Bangladesh, which assessed knowledge, attitude, and the practice of mothers regarding maternity care and nutrition during pregnancy and lactation showed that the health of the mothers was affected by false beliefs and misconceptions about foods and food consumption during and after pregnancy. Most of the foods avoided during and after pregnancy were protein-rich, highly nutritious foods such as fish and eggs. The inaccurate belief that these might lead to the birth of a baby with scabies or skin disease is an example. ${ }^{35}$

One study done in Riyadh, the central region of Saudi Arabia, regarding the dietary habits during pregnancy found 
that avoidances of some types of food, like spicy foods and beverages, is common among pregnant women. The main reasons given for avoiding those foods were undesirable effect on the fetus, heartburn, and no particular reason. ${ }^{36}$

Over half of pregnant women may be consuming more than the recommended amount of calories during pregnancy, according to a research by SMA Nutrition. ${ }^{37}$ Pregnant women tend to eat more than they normally would because they think pregnancy gives them permission to "eat for two."

There are various beliefs and practices about breastfeeding and lactation that are deeply ingrained. Some of these beliefs can be harmful and could be related to the decline in breastfeeding, which has been documented in the Saudi Arabia. ${ }^{38,39}$

The Bella and Dabal ${ }^{40}$ study identifies misperceptions and incorrect beliefs about breastfeeding among Saudi female college students. Some of them believed that breastfeeding would spoil the mother's breasts and figure.

Intercourse during pregnancy is an issue that many women wonder about but are afraid and ashamed to ask. The lack of communication about this sensitive subject has led to many misconceptions. One of the most common myths surrounding this issue is that sex can cause a miscarriage. ${ }^{41}$

The study of knowledge, attitude, and practice of epidural analgesia for labor in Karachi showed $76 \%$ of the females were aware of epidural analgesia as a labor pain-relieving method. However, most of the females had fears that epidural analgesia cause permanent backache, and some of them believed it results in weakness or paralysis of limbs. ${ }^{42}$

Several studies indicated that the incidences of postpartum health problems are high, and these problems may be related to traditional and unscientific dietary and behavioral practices in the postpartum period. ${ }^{43-46}$

In summary, it is obvious that more education is needed for pregnant women during ANC visits to address different aspects related to pregnancy, delivery, and infant care. More organized educational activities should be employed by either physicians, health educators, or nurses.

\section{Acknowledgment}

The research was funded by the King Abdullah International Medical Research Center, Riyadh, Saudi Arabia.

\section{Disclosure}

The authors have no affiliation or financial involvement with organizations or entities with a direct financial interest in the subject matter or materials discussed in the manuscript. This review was completed during the preparation for the research titled "Perceptions and effects of antenatal education," a cross-sectional study, which is available from http://www.ncbi.nlm.nih.gov/pubmed/24343470. The authors report no conflicts of interest in this work.

\section{References}

1. Di Mario S, Basevi V, Gori G, Spettoli D. What is the effectiveness of antenatal care? (Supplement), WHO Regional Office for Europe (Health Evidence Network report); 2005. Available from: http://www.euro.who. int/_data/assets/pdf_file/0005/74660/E87997.pdf

2. Sikorski J, Wilson J, Clement S, Das S, Smeeton N. A randomised controlled trial comparing two schedules of antenatal visits: the antenatal care project. BMJ. 1996;312(7030):546-553.

3. Villar J, Ba'aqeel H, Piaggio G, et al; WHO Antenatal Care Trial Research Group. WHO antenatal care randomised trial for the evaluation of a new model of routine antenatal care. Lancet. 2001;357(9268): $1551-1564$.

4. Lindmark G. Assessing the scientific basis of antenatal care: the case of Sweden. Int J Technol Assess Health Care. 1992;8(Suppl 1):2-7.

5. Munjanja SP, Lindmark G, Nyström L. Randomised controlled trial of a reduced-visits programme of antenatal care in Harare, Zimbabwe. Lancet. 1996;348:364-369.

6. Dhange P, Breeze ACG, Kean LH. Routine antenatal management at the booking clinic. Obstet Gynaecol Reprod Med. 2013;23:45-52.

7. Fawole AO, Okunlola MA, Adekunle AO. Clients' perceptions of the quality of antenatal care. J Natl Med Assoc. 2008;100(9): $1052-1058$

8. WHO Antenatal Care Trial Research Group. WHO Antenatal Care Randomized Trial: Manual for the Implementation of the New Model. Geneva: World Health Organization, Department of Reproductive Health and Research; 2002. Available from: http://whqlibdoc.who.int/ hq/2001/WHO_RHR_01.30.pdf

9. World Health Organization. The World Health Report 2005: Make Every Mother and Child Count. Geneva: World Health Organization; 2005. Available from: http://www.who.int/whr/2005/whr2005_en.pdf

10. WHO, UNICEF. Antenatal Care in Developing Countries. Promises, Achievements and Missed Opportunities: An Analysis of Trends, Levels and Differentials, 1990-2001. Geneva: World Health Organization; 2003. Available from: http://www.childinfo.org/files/antenatal_care.pdf

11. Gerein N, Mayhew S, Lubben M. A framework for a new approach to antenatal care. Int J Gynaecol Obstet. 2003;80(2):175-182.

12. Holmes W. Effective provision of antenatal care. Lancet. 2001; 358(9285):928.

13. Harrison KA. Child-bearing, health and social priorities: a survey of 22,774 consecutive births in Zaria, Northern Nigeria. Br J Obstet Gynaecol. 1985;92(Suppl 5):1-119.

14. Harrison KA. The importance of the educated healthy women in Africa. Lancet. 1997;349(9052):644-647.

15. Carroli G, Rooney C, Villar J. How effective is antenatal care in preventing maternal mortality and serious morbidity? An overview of the evidence. Paediatr Perinat Epidemiol. 2001;15(Suppl 1):1-42.

16. Lumbiganon P. Appropriate technology: antenatal care. Int J Gynecol Obstet. 1998;63(Suppl 1):S91-S95.

17. National Collaborating Centre for Women's and Children's Health. Antenatal Care: Routine Care or the Healthy Pregnant Women; 2005. Available from: www.rcog.org.uk/resources/Public/Antenatal_care. pdf. Accessed September 22, 2009.

18. Institute for Clinical Systems Improvement. Knowledge resources. Routine prenatal care [webpage on the Internet]. 2005. Available from: www.icsi.org/Knowledge/detail.asp. Accessed September 25, 2009.

19. Department of State for Health and Social Welfare: maternal and child health services. Banjul; 1993.

20. Department of State for Health and Social Welfare: National Reproductive Health Policy for The Gambia, 2001-2006. Banjul; 2001.

21. Department of State for Health and Social Welfare: Reproductive health training manual for The Gambia - a guide for health workers. Banjul; 2003.

22. Nigenda G, Langer A, Kuchaisit C, et al. Womens' opinions on antenatal care in developing countries: results of a study in Cuba, Thailand, Saudi Arabia and Argentina. BMC Public Health. 2003;3:17. 
23. Langer A, Villar J, Romero M, et al. Are women and providers satisfied with antenatal care? Views on a standard and a simplified, evidencebased model of care in four developing countries. BMC Womens Health. 2002;2(1):7.

24. Langer A, Nigenda G, Romero M, et al. Conceptual bases and methodology for the evaluation of women's and providers' perception of the quality of antenatal care in the WHO Antenatal Care Randomised Controlled Trial. Paediatr Perinat Epidemiol. 1998;12 Suppl 2:98-115.

25. Villar J, Bakketeig L, Donner A, et al. The WHO antenatal care randomised controlled trial: rationale and study design. Paediatr Perinat Epidemiol. 1998;12 Suppl 2:27-58.

26. Scholle SH, Weisman CS, Anderson R, Weitz T, Freund KM, Binko J. Women's satisfaction with primary care: a new measurement effort from the PHS National Centers of Excellence in Women's Health. Womens Health Issues. 2000;10(1):1-9.

27. Kajuri M, Karimi S, Shekarabi R, Hosseini F. Investigating women's satisfaction with prenatal care received at the primary health care centers of Shirvan Chardaval, Iran in 2005. The Internet Journal of Gynecology and Obstetrics. 2007;7(1).

28. Cham M, Sundby J, Vangen S. Maternal mortality in the rural Gambia, a qualitative study on access to emergency obstetric care. Reprod Health. 2005;2(1):3.

29. von Both C, Flessa S, Makuwani A, Mpembeni R, Jahn A. How much time do health services spend on antenatal care? Implications for the introduction of the focused antenatal care model in Tanzania. BMC Pregnancy Childbirth. 2006;6:22.

30. Mathole T, Lindmark G, Majoko F, Ahlberg BM. A qualitative study of women's perspectives of antenatal care in a rural area of Zimbabwe. Midwifery. 2004;20(2):122-132.

31. Hildingsson I, Waldenström U, Rådestad I. Women's expectations on antenatal care as assessed in early pregnancy: number of visits, continuity of caregiver and general content. Acta Obstet Gynecol Scand. 2002;81(2):118-125.

32. Onah HE. Formal education does not improve the acceptance of cesarean section among pregnant Nigerian women. Int J Gynaecol Obstet. 2002;76(3):321-323.

33. Spector RE, editor. Cultural Diversity in Health and Illness. New York, NY: Appleton-Century-Crofts; 1979.
34. Kaewsarn P, Moyle W, Creedy D. Traditional postpartum practices among Thai women. J Adv Nurs. 2003;41(4):358-366.

35. Al Abdeen Taha AZ, Al Shahri MZ, Sebai ZA. Maternity care and nutrition in a rural area of Bangladesh: a household survey. Bahrain Med Bull. 1996;18(4):1-7.

36. al-Kanhal MA, Bani IA. Food habits during pregnancy among Saudi women. Int J Vitam Nutr Res. 1995;65(3):206-210.

37. Eating for two myth causing diet dilemma for new mums [webpage on the Internet]. Female First; 2009. Available from: http://www. femalefirst.co.uk/parenting/Eating+For+Two+Myth+Causing+Diet+ Dilemma+For+New+Mums-1095.html. Accessed 2010.

38. Lawson M. Infant feeding habits in Riyadh. Saudi Med J. 1981;2: 27-29.

39. Al-Frayh A, Wong SS, Haque KN. Infant feeding practices in Riyadh, Saudi Arabia. Ann Saudi Med. 1988;8(3):194-197.

40. Bella H, Dabal BK. Misperceptions about breastfeeding among Saudi female college students. Ann Saudi Med. 1998;18(1):69-72.

41. Jenkins S. Sex and pregnancy - common myths and little known facts [webpage on the Internet]. Ezine Articles; 2008. Available from: http:// ezinearticles.com/?Sex-and-Pregnancy---Common-Myths-and-LittleKnown-Facts\&id=1041997.

42. Minhas M, Kamal R, Afshan G, Raheel H. Knowledge, attitude and practice of parturients regarding epidural analgesia for labour in a university hospital in Karachi. J Pak Med Assoc. 2005;55(2):63-66.

43. Liu N, Mao L, Sun X, Liu L, Yao P, Chen B. The effect of health and nutrition education intervention on women's postpartum beliefs and practices: a randomized controlled trial. BMC Public Health. 2009;9:45.

44. Mao LM, Sun XF, Liu LG, Cui YJ, Liu CL, Chen BH. The survey and analysis on levels of maternal morbidity during the puerperium and its influencing factors. Chinese J Chronic Diseases. 2004;3(4):89-93.

45. Yuan SY, Chen WQ, Zhang Y. Health survey and requirements of women during the puerperium. Maternal and Child Health Care of China. 2001;16(2):95-96.

46. Cui YJ, Mao LM, Sun XF, Liu LG. The relationship between postpartum food habits and puerperal disorders in rural Hubei. Chinese Journal of Nursing. 2006;1:43-44.
International Journal of Women's Health

\section{Publish your work in this journal}

The International Journal of Women's Health is an international, peerreviewed open-access journal publishing original research, reports, editorials, reviews and commentaries on all aspects of women's healthcare including gynecology, obstetrics, and breast cancer. The manuscript management system is completely online and includes

\section{Dovepress}

a very quick and fair peer-review system, which is all easy to use. Visit http://www.dovepress.com/testimonials.php to read real quotes from published authors. 